\title{
Relationship between peripheral and mesenteric serum levels of CEA and CA 242 with staging and histopathological variables in colorectal adenocarcinoma ${ }^{1}$
}

\author{
Níveis séricos periféricos e mesentéricos de CEA e CA 242, estadiamento e variáveis \\ histopatológicas no adenocarcinoma colorretal
}

\author{
Mauro Lamelas Cardoso ${ }^{\mathrm{I}}$, Luís Cesar Fernandes ${ }^{\mathrm{II}}$, Su Bong Kim ${ }^{\mathrm{III}}$, Delcio Matos ${ }^{\mathrm{IV}}$ \\ ${ }^{\text {I }}$ Master, Gastroenterology Surgery, UNIFESP, Sao Paulo, Brazil. \\ II Affiliate Professor, Surgical Gastroenterology, Department of Surgery, School of Medicine, UNIFESP, Sao Paulo, Brazil. \\ III Affiliate Professor, Surgical Gastroenterology, Department of Surgery, School of Medicine, UNIFESP, Sao Paulo, Brazil. \\ IV Full Professor, Surgical Gastroenterology, Department of Surgery and Dean of Postgraduate Program of Surgical Gastroenterology, School of \\ Medicine, UNIFESP, Sao Paulo, Brazil.
}

\begin{abstract}
Purpose: To compare histopathological variables and staging in colorectal adenocarcinoma cases with CEA and CA 242 in peripheral and mesenteric blood. Methods: In 169 individuals underwent surgery for colorectal cancer, CEA and CA 242 were analyzed and compared to mesenteric and peripheral blood and correlated with macroscopic tumor's morphology and size, degree of cell differentiation, venous, neural and lymphatic involvement and TNM classification. Results: There was a difference between the mesenteric $(\mathrm{M})$ and peripheral $(\mathrm{P})$ serum levels of CEA $(\mathrm{p}=0.020)$. Higher levels of markers were correlated with venous invasion CEA (P) $\mathrm{p}=0.013$, CEA (M) $\mathrm{p}=0.05, \mathrm{CA} 242(\mathrm{M}) \mathrm{p}=0.005$ and CA $242(\mathrm{P}) \mathrm{p}=0.038$; with advanced staging CEA $(\mathrm{P})<\mathrm{CEA}(\mathrm{M})(\mathrm{p}<0.05)$; CA $242(\mathrm{P})<\mathrm{CA} 242(\mathrm{M})(\mathrm{p}<0.05)$; and with greater dimensions CEA $(\mathrm{P})<$ CEA $(\mathrm{M})(\mathrm{p}<0.001)$; CA $242(\mathrm{P})<$ CA $242(\mathrm{M})(\mathrm{p}<0.001)$. CA 242 became higher with neural invasion $(\mathrm{P})$ : $\mathrm{p}=0.014,(\mathrm{M}): \mathrm{p}=0.003)$. Conclusions: There were higher mesenteric than peripheral levels of CEA. Both mesenteric and peripheral levels of CEA and CA 242 were higher in neoplasm with venous involvement, greater diameter and advanced stages. There was a correlation between CA 242 and neural invasion.
\end{abstract}

Key words: Adenocarcinoma. Prognosis. Tumor Markers, Biological. Colon. Rectum.

\section{RESUMO}

Objetivo: Comparar variáveis histopatológicas e graus de estadiamento do adenocarcinoma colorretal com níveis sanguíneos periféricos e mesentéricos de CEA e CA-242. Métodos: Em 169 doentes submetidos ao tratamento cirúrgico por adenocarcinoma colorretal, CEA e CA-242 foram analisados e comparados quanto aos níveis sanguíneos periféricos e mesentéricos e correlacionados com o tamanho e a morfologia macroscópica do tumor, grau de diferenciação celular, invasões venosa, linfática, neural e a classificação TNM. Resultados: Verificou-se diferença significante entre o nível sérico mesentérico e periférico de CEA ( $p=0,02)$. Níveis séricos mais elevados dos marcadores foram observados e correlacionados com invasão venosa, CEA (P) p=0,013, CEA(M), p=0,05, CA-242 (M) $\mathrm{p}=0,005$ e CA-242 (P) p=0,038. Grau de estadiamento TNM avançado foi associado com CEA(P) $<\mathrm{CEA}(\mathrm{M}) \mathrm{p}<0,05, \mathrm{CA}-242(\mathrm{P})<$ $\mathrm{CA}-242(\mathrm{M}) \mathrm{p}<0,05$. Nas maiores dimensões tumorais constatou-se $\mathrm{CEA}(\mathrm{P})<\mathrm{CEA}(\mathrm{M}) \mathrm{p}=0,001$ e CA $242(\mathrm{P})<\mathrm{CA} 242(\mathrm{M})(\mathrm{p}<0.001)$. O CA 242 periférico e mesentérico aumentados associaram-se com a invasão neural, $p=0.014$ e p=0.003, respectivamente. Conclusões: O nível sérico mesentérico de CEA é superior ao nível sérico periférico. Os níveis séricos mesentéricos e periféricos do CEA e do CA-242 são mais elevados no adenocarcinoma com invasão venosa, de maior diâmetro e de estadios avançados. Existe uma associação entre o nível sérico do Ca-242 e a invasão neural.

Descritores: Adenocarcinoma. Prognóstico. Marcadores Biológicos de Tumor. Colo. Reto.

${ }^{1}$ Research performed at Coloproctology Unit, Division of Surgical Gastroenterology, Department of Surgery, Federal University of Sao Paulo UNIFESP), Brazil.

\section{Introduction}

Colorectal cancer is the third most common cause of cancer worldwide in both sexes and the second cause in developed countries. Geographical patterns are similar between men and women; however, rectal cancer is around $20-50 \%$ higher in men in the majority of populations ${ }^{1}$.

The estimated number of new cases of colorectal cancer in Brazil for the year 2008 is 12,490 in men and 14,500 in women, corresponding to an estimated risk of 13 new cases per 100,000 men and 15 per 100,000 women $^{1}$. The greatest incidence is in the age group between 50 and 70 years old, and it may develop from the age of 40 onwards. 
Survival is considered good with this type of cancer if the disease is diagnosed at an early stage. Global mean 5-year survival rates vary from 40 to $50 \%$ and no great differences are found between developed and developing countries ${ }^{1}$. Attempts have been made to develop more efficient tracking methods and identify prognostic factors that could assist in the administration of more aggressive therapy in selected cases ${ }^{2}$.

Tumor markers are substances present in tumor, blood or other biological fluids that are produced by patients or by neoplastic cells. They can be used for screening, for diagnosis, for establishing prognosis, for monitoring treatment, and for detecting relapse ${ }^{3}$.

One of the markers of great use for colorectal neoplasia is carcinoembryonic antigen (CEA), which was described by Gold \& Freedman ${ }^{4}$ in 1965. CEA is not specific for colorectal cancer, and can present high levels in non-malignant clinical situations (pancreatitis, perforated ulcers, liver cirrhosis and smoking) and in malignant situation in other organs (stomach, lungs and ovaries) ${ }^{5}$. However, it remains the best marker for colorectal neoplasia ${ }^{6}$.

Other markers have emerged: cytokeratins (TPA) and cell membrane glycoproteins (CA 19-9, CA 242 and CA 72-4) $)^{6}$. Like CEA, the preoperative levels of CA 242 may have their importance in determining survival, just as postoperative assaying may assist in determining recurrences of colorectal cancer ${ }^{7}$.

The correlation between the tumor marker levels in the peripheral and mesenteric blood is controversial ${ }^{8}$. Blood collection directly from the drainage veins of the colorectal tumor could predict metastasis to the liver. Some authors have observed significantly higher levels of CEA in the mesenteric blood ${ }^{9,10}$, while others have not observed any significant difference ${ }^{11}$.

Comparisons between the CA 242 and CEA levels in the peripheral and mesenteric blood and their correlations with disease staging and histopathological variables have not yet been completely clarified in the literature. Because these correlations are important for better comprehension of these tumor markers and consequently for obtaining progress in treatments for patients, they comprise the objective of the present investigation.

\section{Methods}

This was a retrospective study of the medical records and database of the Coloproctology Group, Discipline of Surgical Gastroenterology, Department of Surgery, Federal University of Sao Paulo - School of Medicine (UNIFESP - EPM), at Sao Paulo's Hospital. The studied sample was 169 patients with colorectal adenocarcinoma who underwent surgical intervention between March 1993 and December 2000, attended consecutively. The present research was approved by the institutional ethics committee.

Patients were not included in the study if they had a previous history of other neoplasias (whether benign or malignant); if they did not agree with the experiment; or if they were not available for periodic postoperative clinical follow-up.

Ninety-six patients $(56.8 \%)$ were women. The patients' ages ranged from 19 to 89 years, with a mean of 62.2 years (standard deviation $(\mathrm{SD})=13.2)$. One hundred and sixteen patients were white $(69.2 \%), 13(7.7 \%)$ were yellow, $5(3.0 \%)$ were black and 34 $(20.1 \%)$ were brown. With regard to location, 39 patients $(23.1 \%)$ presented neoplasia in the right colon, $6(3.6 \%)$ in the transverse colon, $32(18.9 \%)$ in the left colon and $92(54.4 \%)$ in the rectum.
Amongst 169 patients, resection of the neoplasia was possible in 154 cases. Following surgical removal of the tumor, the material was fixed in formol, labeled and sent to the Pathological Anatomy Laboratory of Sao Paulo's Hospital - School of Medicine, where it was analyzed.

One hundred and twenty patients $(77.9 \%)$ presented ulcerated tumor lesions, 76 (49.4\%) vegetating lesions and 70 $(45.4 \%)$ infiltrating lesions (several patients presented mixed types of lesions). Analysis under the microscope showed that 25 patients (17.2\%) presented signs of venous invasion, 48 (31.2\%) lymphatic invasion and $40(26.0 \%)$ neural invasion. The mean diameter of tumor lesions was $6.1 \mathrm{~cm}(\mathrm{SD}=2.7 \mathrm{~cm})$. Sixty-five patients $(42.2 \%)$ presented well-differentiated tumors, 86 (55.9\%) moderately differentiated tumors, three $(2.0 \%)$ poorly differentiated tumors and there were no cases of undifferentiated tumors. TNM system was used for staging.

Peripheral blood was collected by venous puncture in the arm that was not being used for infusion of substances or hydration while anesthesia was being induced. The serum was separated by centrifugation and stored at $-20^{\circ} \mathrm{C}$.

Mesenteric blood was collected by catheterization of the tributary vein corresponding to the site of colorectal adenocarcinoma that was being resected: for tumors in the left colon and rectum, the inferior mesenteric vein; for tumors in the transverse colon, the middle colic vein; and for tumors in the right colon, the corresponding wide tributary vein and finishing in the superior mesenteric vein. This procedure was performed before any manipulation of the tumor, and the samples were processed and stored at the same way that those obtained from the peripheral blood.

The markers were assayed in the Clinical Analyses Laboratory of Sao Paulo's Hospital. To quantify CEA (carcinoembryonic antigen), the Delfia ${ }^{\circledR}$ method, based on immunofluorescence, was used, and values less than $5 \mathrm{ng} / \mathrm{ml}$ were considered normal ${ }^{8}$. The assaying of CA 242 was performed by the immunoenzymatic method (EIE). Expression of up to 20 $\mathrm{U} / \mathrm{ml}$ was considered normal ${ }^{7,8}$.

The statistical analyze was performed by descriptive analysis of the data, using summary measurements. The inferential analysis consisted of two situations: association between the markers and a categorical variable and association between the markers and a numerical variable. For the first case, Fisher's exact test was used, and Student's t test for unrelated samples was applied for the second one. For calculation purposes, the data were transformed into logarithms. Statistical differences with a level of 0.05 or $5 \%$ $(\alpha \leq 0.05)$ were considered significant.

\section{Results}

Comparison between the peripheral and mesenteric serum levels of the tumor markers demonstrated that the measurements differed for CEA(P): $23.88 \mathrm{ng} / \mathrm{ml} \pm 95.46 \mathrm{ng} / \mathrm{ml}$; (M): 39, $10 \mathrm{ng} / \mathrm{ml}$ $\pm 121.19 \mathrm{ng} / \mathrm{ml}(\mathrm{p}=0.020)$ but not for CA $242(\mathrm{P}): 89.53 \mathrm{U} / \mathrm{ml} \pm$ $397.73 \mathrm{U} / \mathrm{ml},(\mathrm{M}): 94.88 \mathrm{U} / \mathrm{ml} \pm 404.79 \mathrm{U} / \mathrm{ml}(\mathrm{p}=0.42)$.

Correlating the tumor markers and the macroscopic morphology of lesions, no statistical association was found.

High levels of markers correlate with venous invasion: Patients who had vessel invasion, in pathological analyzes, showed high levels of CEA (M) in $60.9 \%$. Those who had not venous invasion showed $37.6 \%$ of abnormal values $(p=0,05)$. In the same 
way, CEA (P) level was increased in $64 \%$ of patients with venous invasion, and elevated in $37.7 \%$ without vessel involvement $(\mathrm{p}=0.013)$. CA $242(\mathrm{M})$ was increased in $56.5 \%$ of patients who had venous invasion and elevated in $25 \%$ of patients without venous invasion $(\mathrm{p}=0.005)$. Patients with venous involvement by tumor had $47.8 \%$ of high levels of CA 242 (P) detected, whereas $24 \%$ of the patients without venous invasion also had this high marker level $(\mathrm{p}=0,038)$ (Table 1$)$.

None of the markers showed any association with lymphatic involvement.

TABLE 1 - Correlation between markers and venous invasion

\begin{tabular}{|c|c|c|c|c|}
\hline & \multicolumn{4}{|c|}{ VENOUS INVASION } \\
\hline & & NO & YES & $p$ \\
\hline \multirow{3}{*}{$\begin{array}{l}\text { MESENTERIC } \\
\text { CEA }\end{array}$} & NORMAL LEVEL & $63(62.4 \%)$ & $9(39.1 \%)$ & \\
\hline & HIGH LEVEL & $38(37.6 \%)$ & $14(60.9 \%)$ & $0.050^{*}$ \\
\hline & TOTAL PATIENTS & 101 & 23 & \\
\hline \multirow{3}{*}{$\begin{array}{c}\text { PERIPHERIC } \\
\text { CEA }\end{array}$} & NORMAL LEVEL & $83(64.3 \%)$ & $9(36 \%)$ & \\
\hline & HIGH LEVEL & $46(37.7 \%)$ & $16(64 \%)$ & $0.013^{*}$ \\
\hline & TOTAL PATIENTS & 129 & 25 & \\
\hline \multirow{3}{*}{$\begin{array}{c}\text { MESENTERIC } \\
\text { CA } 242\end{array}$} & NORMAL LEVEL & $75(75 \%)$ & $10(43.5 \%)$ & \\
\hline & HIGH LEVEL & $25(25 \%)$ & $13(56,5 \%)$ & $0.005^{*}$ \\
\hline & TOTAL PATIENTS & 100 & 23 & \\
\hline \multirow{3}{*}{$\begin{array}{c}\text { PERIPHERIC } \\
\text { CA } 242\end{array}$} & NORMAL LEVEL & $76(76 \%)$ & $12(52,2 \%)$ & \\
\hline & HIGH LEVEL & $24(24 \%)$ & $11(47,8 \%)$ & $0.038^{*}$ \\
\hline & TOTAL PATIENTS & 100 & 23 & \\
\hline
\end{tabular}

Regarding to neural invasion, more abnormal values of CA 242 were found. In peripheral blood, 22.2\% patients had high CA 242 levels and no neural invasion and 47.8\% had high levels, but neural invasion was established $(\mathrm{p}=0.014)$; in mesenteric blood,
$23.3 \%$ and $51.5 \%$ of abnormal levels were found, in the absence and in the presence of neural invasion, respectively $(p=0.003)$. No significant statistical differences were detected in CEA levels (P) $\mathrm{p}=0.574$ and $(\mathrm{M}) \mathrm{p}=0.414$ (Table 2).

TABLE 2 - Correlation between markers and neural invasion

\begin{tabular}{|c|c|c|c|c|}
\hline & \multicolumn{4}{|c|}{ NEURAL INVASION } \\
\hline & & NO & YES & $p$ \\
\hline \multirow{3}{*}{$\begin{array}{c}\text { MESENTERIC } \\
\text { CEA }\end{array}$} & NORMAL LEVEL & $55(60.5 \%)$ & $17(51.5 \%)$ & \\
\hline & HIGH LEVEL & $36(39.5 \%)$ & $16(48.5 \%)$ & 0,414 \\
\hline & TOTAL PATIENTS & 91 & 33 & \\
\hline \multirow{3}{*}{$\begin{array}{c}\text { PERIPHERIC } \\
\text { CEA }\end{array}$} & NORMAL LEVEL & $70(61.4 \%)$ & $22(55 \%)$ & \\
\hline & HIGH LEVEL & $44(38.6 \%)$ & $18(45 \%)$ & 0,574 \\
\hline & TOTAL PATIENTS & 114 & 40 & \\
\hline \multirow{3}{*}{$\begin{array}{c}\text { MESENTERIC } \\
\text { CA } 242\end{array}$} & NORMAL LEVEL & $69(76,7 \%)$ & $16(48.8 \%)$ & \\
\hline & HIGH LEVEL & $21(23.3 \%)$ & $17(51,5 \%)$ & $0,003^{*}$ \\
\hline & TOTAL PATIENTS & 90 & 33 & \\
\hline \multirow{3}{*}{$\begin{array}{c}\text { PERIPHERIC } \\
\text { CA } 242\end{array}$} & NORMAL LEVEL & $70(77,8 \%)$ & $18(52,2 \%)$ & \\
\hline & HIGH LEVEL & $20(22.2 \%)$ & $15(47,8 \%)$ & $0,014^{*}$ \\
\hline & TOTAL PATIENTS & 90 & 33 & \\
\hline
\end{tabular}


Correlating the markers with the tumor diameter, mesenteric and peripheral CEA and CA 242 showed a direct association with the tumor diameter (Table 3 ).
Comparing the degree of cell differentiation with the levels of markers, no significant statistical relationship was shown.

TABLE 3 - Correlation between markers and tumor size

\begin{tabular}{ccccc}
\hline & & \multicolumn{2}{c}{ TUMOR SIZE (cm) } & \\
\hline & & MEAN & SD & p \\
\hline MESENTERIC & NORMAL LEVEL & 5.75 & 2.45 & $035^{*}$ \\
CEA & HIGH LEVEL & 6.37 & 2.82 & \multirow{2}{*}{$0,001^{*}$} \\
\hline PERIPHERIC & NORMAL LEVEL & 5.49 & 2.37 & \\
CEA & HIGH LEVEL & 6.95 & 2.84 & $0,011^{*}$ \\
\hline MESENTERIC & NORMAL LEVEL & 5.77 & 2.52 & \\
CA 242 & HIGH LEVEL & 6.46 & 2.80 & $0,008^{*}$ \\
\hline \multirow{2}{*}{ PERIPHERIC } & NORMAL LEVEL & 5.78 & 2.48 & \\
CA 242 & HIGH LEVEL & 6.48 & 2.86 & \\
\hline
\end{tabular}

SD: standard deviation

Considering the TNM classification, both markers presented significant correlations with staging (Table 4).

TABLE 4 - Difference between mesenteric and peripheral marker's levels

\begin{tabular}{l|c|c|c|c|c}
\hline & Stage I & Stage II & Stage III & Stage IV & \\
\hline CEA P $(\mathrm{ng} / \mathrm{ml})$ & $14.2 \pm 48.5$ & $8.5 \pm 29.3$ & $8.0 \pm 15.5$ & $87.7 \pm 187.8$ & $p<0.05$ \\
\cline { 1 - 4 } CEA M $(\mathrm{ng} / \mathrm{ml})$ & $15.0 \pm 43.0$ & $3.7 \pm 3.2$ & $11.3 \pm 21.2$ & $90.3 \pm 190.1$ & \\
\hline CA 242 P (U/ml) & $9.0 \pm 10.3$ & $15.7 \pm 16.4$ & $26.1 \pm 38.4$ & $219.1 \pm 650.8$ & \multirow{2}{*}{$p<0.05$} \\
\hline CA 242 M (U/ml) & $9.5 \pm 11.9$ & $16.8 \pm 18.2$ & $28.4 \pm 38.7$ & $227.8 \pm 661.2$ & \\
\hline
\end{tabular}

$\mathrm{P}=$ peripheral

$\mathrm{M}=$ mesenteric 


\section{Discussion}

The success in treating the cancer disease directly depends the stage when the diagnosis is made. Thus, it is fundamentally important to recognize the neoplasm at an early stage. The most important objective of researching serological markers and their correlation with histopathological variables is to identify factors that could be correlated to the prognosis of the disease.

The increased CEA levels in the mesenteric serum, and their relation to the peripheral serum, are compatible with the findings of Tabuchi et al. ${ }^{9,10}$, who suggested that the drainage of CEA takes place mainly via the portal system. In the present investigation, this situation was corroborated, which makes it possible to put forward the same hypothesis. Measurement of this marker in the mesenteric blood could increase the sensitivity of the method in relation to the conventional one and could perhaps allow to predict which cases could present extra-colonic disease, hepatic micrometastasis, and which ones could be potential candidates for more aggressive therapeutic schemes, that could increase time and quality of life. Regarding to CA 242, there was no significant statistical difference between the levels found at the two sites, but this marker seems to be as useful as CEA for assaying in mesenteric blood.

Comparing tumor markers with lesion morphology, no significant statistical difference were detected between vegetating, ulcerated or infiltrative tumors. The macroscopic aspect did not show any correlation with normal and abnormal values of these two markers.

The importance of neural, lymphatic and vascular invasion on survival and on the prognosis for colorectal cancer has already been the topic of many researches in the literature ${ }^{2,12}$, and it has been shown that the involvement of these structures is associated with worse prognosis.

The studies by Tabuchi et al..$^{9,10}$ showed higher levels of mesenteric and peripheral CEA correlated with venous invasion. In the present study, like them, higher peripheral and mesenteric levels of CEA were found in patients with colorectal adenocarcinoma with venous invasion.

A statistical association with venous system invasion was also found CA 242, both in peripheral than mesenteric blood assays. This emphasizes the importance of this marker and opens up the possibility of developing new studies that correlate this marker with survival and staging. It may suggest that the drainage route for this marker is preponderantly hematogenic, via the mesenteric-portal system.

Tabuchi et al. ${ }^{10}$ were able to demonstrate an association between mesenteric CEA levels and the presence of lymphatic invasion, which was not confirmed in the present investigation.

Regarding to neural involvement, the marker CA 242 in mesenteric and peripheral serum showed to be better than CEA to predict the invasion of these structures.

Evaluating the prognostic factors for colorectal cancer in the consensus of the College of American Pathologists, Compton et al. ${ }^{13}$ considered that the tumor dimensions measured after surgical remove were a variable of low interest regarding the evolution of the disease. Measurement of the tumor diameter and its correlation with normal or abnormal levels of tumor markers has the objective of identifying which ones are related to earlier or later neoplastic lesions. Studies have shown that peripheral and mesenteric CEA levels are higher when associated with larger lesions ${ }^{10}$. It is suggested that with greater volumes of neoplastic cells, the quantity of the tumor marker produced and released into the circulation ought to be greater.

Comparing the groups of patients with normal and abnormal levels of CEA and CA 242 (assayed in the peripheral and mesenteric serum) with the TNM staging, both of these markers showed statistical significance for this variable.

Forones et $a l .{ }^{14}$ retrospectively studied peripheral CEA levels in 83 patients with regard to prognoses for colorectal cancer and correlated these with the Dukes staging. They found that CEA had a capacity to differentiate stage A from stage $\mathrm{C}$ and $\mathrm{C}$ from $\mathrm{B}$, but not A from B. In another study on 240 patients with colorectal cancer $^{15}$, the same authors were able, by the increased CEA levels, to differentiate the patients in stage $\mathrm{B}$ from stage $\mathrm{D}$ and $\mathrm{C}$ from $\mathrm{D}$, but not those in B from $\mathrm{C}$.

In the present investigation, this power of discrimination was not attained. However, stages I, II and III of the TNM classification were clearly differentiated from stage IV. It is believed that, in cases of extra-colonic disease, with extension to adjacent and distant organs and structures, a significant increase in the production and release of tumor markers takes place.

It is known that tumors with less differentiation are associated with worse prognosis for recurrence and survival ${ }^{13}$. Other studies, however, have not found significant statistical correspondence for this variable ${ }^{12}$. In the present study, it was not possible to identify any relationship between the markers and the degree of cell differentiation of the tumors. This requires new studies and investigations.

The ideal marker does not exist yet, but attempts continue towards obtaining better comprehension of the metabolism of the existing markers, with the aim of optimizing their utilization and consequently improving the medical supervision of patients with colorectal adenocarcinoma ${ }^{16,17}$.

\section{References}

1. Brasil. Ministério da Saúde. Coordenação de Prevenção e Vigilância de Câncer. Estimativas 2008: Incidência de Câncer no Brasil. Rio de Janeiro: INCA; 2007.

2. Meguerditchian AN, Bairati I, Lagace R, Harel F, Kibrite A. Prognostic significance of lymphovascular invasion in surgically cured rectal carcinoma. Am J Surg. 2005;189(6):707-13.

3. Bates SE. Clinical applications of serum tumor markers. Ann Intern Med. 199115;115(8):623-38.

4. Gold P, Freedman SO. Specific carcinoembryonic antigens of the human digestive system. J Exp Med. 1965;122(3):467-81.

5. Thomas P, Zamcheck N. Role of the liver in clearance and excretion of circulating carcinoembryonic antigen (CEA). Dig Dis Sci. 1983;28(3):216-24

6. Carpelan-Holmstrom M, Louhimo J, Stenman UH, Alfthan H, Jarvinen H, Haglund C. CEA, CA 242, CA 19-9, CA 72-4 and hCGbeta in the diagnosis of recurrent colorectal cancer. Tumour Biol. 2004;25(5-6):228-34

7. Carpelan-Holmstrom M, Haglund C, Lundin J, Jarvinen H, Roberts P. Pre-operative serum levels of CA 242 and CEA predict outcome in colorectal cancer. Eur J Cancer. 1996;32A(7):1156-61.

8. Kim SB, Fernandes LC, Saad SS, Matos D. Assessment of the value of preoperative serum levels of CA 242 and CEA in the staging and postoperative survival of colorectal adenocarcinoma patients. Int J Biol Markers. 2003;18(3):182-7. 
9. Tabuchi Y, Deguchi H, Imanishi K, Saitoh Y. Colorectal cancer patients with high risk of hematogenous metastasis: correlation with CEA levels in peripheral and draining venous blood during the period of operation. J Surg Oncol. 1991;47(2):87-91.

10. Tabuchi Y, Deguchi H, Imanishi K, Saitoh Y. Comparison of carcinoembryonic antigen levels between portal and peripheral blood in patients with colorectal cancer. Correlation with histopathologic variables. Cancer. 1987;59(7):1283-8.

11. Waisberg J, Contim-Neto L, Oliveira MS, Matheus CO, Nagashima CA, Goffi FS. Determination of carcinoembryonic antigen levels in peripheral and draining venous blood in patients with colorectal carcinoma. Arq Gastroenterol. 2004;41(2):88-92.

12. Knudsen JB, Nilsson T, Sprechler M, Johansen A, Christensen N. Venous and nerve invasion as prognostic factors in postoperative survival of patients with resectable cancer of the rectum. Dis Colon Rectum. 1983;26(9):613-7.

13. Compton CC, Fielding LP, Burgart LJ, Conley B, Cooper HS, Hamilton SR, Hammond ME, Henson DE, Hutter RV, Nagle RB, Nielsen ML, Sargent DJ, Taylor CR, Welton M, Willett C. Prognostic factors in colorectal cancer. College of American Pathologists Consensus Statement 1999. Arch Pathol Lab Med. 2000;124(7):979-94.
14. Forones NM, Tanaka M, Falcao JB. CEA as a prognostic index in colorectal cancer. Sao Paulo Med J. 1997;115(6):1589-92.

15. Forones NM, Tanaka M, Machado D, Falcao JB, Giovanoni M. Carcinoembryonic antigen in diagnosis and monitoring of colorectal cancer. Arq Gastroenterol. 1997;34(1):3-6.

16. Fernandes LC, Kim SB, Matos D. Cytokeratins and carcinoembryonic antigen in diagnosis, staging and prognosis of colorectal adenocarcinoma. World J Gastroenterol. 2005;11(5):645-8.

17. Fernandes LC, Kim SB, Saad SS, Matos D. Value of carcinoembryonic antigen and cytokeratins for the detection of recurrent disease following curative resection of colorectal cancer. World J Gastroenterol. 2006;12(24):3891-4.

Conflict of interest: none Financial Source: none

\section{Correspondence:}

Dr. Mauro Lamelas Cardoso

Rua Ovídio Abrantes, 169

09424-150 Ribeirao Pires - SP Brazil

Phone: (55 11)4827-6273 / 8187-8545

lamelas.mauro@uol.com.br

Received: March 18, 2009

Review: May 12, 2009

Accepted: June 16, 2009

\section{How to cite this article}

Cardoso ML, Fernandes LC, Kim SB, Matos D. Relationship between peripheral and mesenteric serum levels of CEA and CA 242 with staging and histopathological variables in colorectal adenocarcinoma. Acta Cir Bras. [serial on the Internet] 2009 Sept-Oct;24(5). Available from URL: http://www.scielo.br/acb 